\section{Isotopic and Nonisotopic Estimation of Nitrogen Uptake Efficiency in Container-grown Woody Ornamentals}

\author{
David R. Sandrock, ${ }^{1}$ Timothy L. Righetti, and Anita N. Azarenko \\ Department of Horticulture, Oregon State University, 4017 Agriculture and \\ Life Sciences Building, Corvallis, OR 97331
}

Additional index words. fertilizer tracer, ${ }^{15} \mathrm{~N}$, Cornus, Weigela, Euonymus

\begin{abstract}
Cornus sericea L., Weigela florida (Bunge) A. DC., and Euonymus alatus (Thunb.) Sieb were grown outside in 3.8-L plastic containers for 345 days (1 Apr. 2001 to 11 Mar. 2002). Nitrogen (N) was applied at rates (NAR) of $25,50,100,200$, and $300 \mathrm{mg} \cdot \mathrm{L}^{-1}$ and delivered as aqueous double-labeled ${ }^{15} \mathrm{~N}$ depleted $\mathrm{NH}_{4} \mathrm{NO}_{3}\left(\min 99.95 \%\right.$ atom $\left.{ }^{14} \mathrm{~N}\right)$. In all species, root, shoot, and total plant dry weight increased with increasing NARs while root to shoot ratios decreased. Similarly, root, shoot, and total plant $N$ increased with NAR for each species, and at each NAR more $\mathrm{N}$ was stored in the roots than in the shoots. Estimation of fertilizer $\mathbf{N}$ uptake determined by the total $\mathbf{N}$ method was higher for all species and at each NAR than estimation of $\mathrm{N}$ uptake determined by the fertilizer ${ }^{15} \mathrm{~N}$ tracer method. Fertilizer $\mathrm{N}$ uptake efficiency determined by the total $\mathrm{N}$ method was highest at $25 \mathrm{mg} \cdot \mathrm{L}^{-1}$ and decreased as NARs increased. In contrast fertilizer $\mathbf{N}$ uptake efficiency determined by the fertilizer ${ }^{15} \mathrm{~N}$ tracer method was lowest at $25 \mathrm{mg} \cdot \mathrm{L}^{-1}$ and increased or remained relatively constant as NARs increased. Differences in $\mathrm{N}$ uptake and $\mathrm{N}$ uptake efficiency can be attributed to overestimation by the total $\mathrm{N}$ method due to the inclusion of nonfertilizer $\mathrm{N}$ and underestimation by the fertilizer ${ }^{15} \mathrm{~N}$ tracer method due to pool substitution. Corrected $\mathrm{N}$ uptake efficiency values can be calculated by adjusting the original data (total $\mathrm{N}$ or ${ }^{15} \mathrm{~N}$ uptake) by the distance between the origin and the $\mathrm{y}$ intercept of the regression line representing the data.
\end{abstract}

Knowledge of fertilizer nitrogen $(\mathrm{N})$ uptake and fertilizer $\mathrm{N}$ uptake efficiency in container-grown nursery crops is necessary for the development of fertilizer schedules that match timing, amount, and frequency of $\mathrm{N}$ applications to plant $\mathrm{N}$ requirements. They are fundamental measures on which research is developed and fertilizer recommendations are made. Therefore, it is essential to employ methods that accurately determine fertilizer $\mathrm{N}$ uptake and fertilizer $\mathrm{N}$ uptake efficiency.

Fertilizer $\mathrm{N}$ uptake and fertilizer $\mathrm{N}$ uptake efficiency in container-grown nursery crops can be determined by the total $\mathrm{N}$ method or by using a stable $\mathrm{N}$ isotope $\left({ }^{15} \mathrm{~N}\right.$ or $\left.{ }^{13} \mathrm{~N}\right)$ as a fertilizer tracer. Each method has inherent components that may compromise the validity of the measurement or interpretation.

Using the total $\mathrm{N}$ method, values of fertilizer N uptake and fertilizer $\mathrm{N}$ uptake efficiency are calculated from equations that actually represent total plant $\mathrm{N}$ uptake and total plant $\mathrm{N}$ uptake efficiency. The total $\mathrm{N}$ method uses the following equation (or a similar form) to calculate fertilizer N uptake: $\mathrm{N}_{\text {termination }}-\mathrm{N}_{\text {initiation }}$ $=\mathrm{TNG}$, where $\mathrm{N}_{\text {termination }}=\mathrm{N}$ in the plant at the termination of the study; $\mathrm{N}_{\text {initiation }}=\mathrm{N}$ in the plant before $\mathrm{N}$ applications; and $\mathrm{TNG}=$ total nitrogen gain during the study and is assumed to be representative of fertilizer $\mathrm{N}$ uptake.

TNG is a measure of total $\mathrm{N}$ uptake and includes $\mathrm{N}$ from sources other than fertilizer (i.e., substrate $\mathrm{N}$ or $\mathrm{N}$ from irrigation water).

Received for publication 14 Sept. 2004. Accepted for publication 17 Nov. 2004.

'Reprint requests; e-mail dsandrock@ifas.ufl.edu.
However, because unamended soilless substrates (e.g., bark, peatmoss, sand) contain relatively small amounts of $\mathrm{N}$ and contribute little toward plant health and vigor (Whitcomb, 1986; Bunt, 1988), TNG is often accepted as a measure of fertilizer $\mathrm{N}$ uptake. Consequently, many studies have used the total $\mathrm{N}$ method to calculate fertilizer $\mathrm{N}$ uptake and fertilizer $\mathrm{N}$ uptake efficiency in container-grown crops (Ivy et al., 2002; Rose and Biernacka, 1999; Rose et al., 1994; Tolman et al., 1990; Tyler et al., 1996).

Similarly, the total $\mathrm{N}$ method uses the following formula to calculate fertilizer $\mathrm{N}$ uptake efficiency: $(\mathrm{TNG} / \mathrm{FNA}) \times 100=$ fertilizer $\mathrm{N}$ uptake efficiency, where $\mathrm{TNG}=$ total nitrogen gain during the study and FNA = the total amount of fertilizer $\mathrm{N}$ applied.

The total $\mathrm{N}$ method does not distinguish fertilizer $\mathrm{N}$ from nonfertilizer $\mathrm{N}$ and assume that the contribution of $\mathrm{N}$ from nonfertilizer sources is too small to significantly affect results.

${ }^{15} \mathrm{Nitrogen}$ fertilizer tracers are regarded as a superior method for determining fertilizer $\mathrm{N}$ uptake and fertilizer $\mathrm{N}$ uptake efficiency because they are more accurate (Hauck and Bremner, 1976), and treatment effects are detected with greater sensitivity (Russelle et al., 1981). In addition, ${ }^{15} \mathrm{~N}$ tracers serve to distinguish fertilizer $\mathrm{N}$ from nonfertilizer $\mathrm{N}$, and allow the direct calculation of fertilizer $\mathrm{N}$ uptake and fertilizer $\mathrm{N}$ uptake efficiency without the inclusion of $\mathrm{N}$ from nonfertilizer sources (Torbert et al., 1992). In the fertilizer ${ }^{15} \mathrm{~N}$ tracer method, isotopic composition is determined by mass spectrometry and atom percent ${ }^{15} \mathrm{~N}$ values are converted to $\mathrm{N}$ derived from fertil- izer (NDFF) using a variation of the following formula (adapted from Hauck and Bremner, 1976): [( $\left.\left({ }^{15} \mathrm{~N}_{\text {natural abundance }}\right)-\left(\text { atom } \%{ }^{15} \mathrm{~N}\right)_{\text {tissue }}\right] /$ $\left[\left({ }^{15} \mathrm{~N}_{\text {naturalabundance }}\right)-\left(\text { atom } \%{ }^{15} \mathrm{~N}\right)_{\text {fertilizer }}\right]=\mathrm{NDFF}$, where ${ }^{15} \mathrm{~N}_{\text {natural abundance }}$ is considered equal to 0.366 atom percent $\left(\text { atom } \%{ }^{15} \mathrm{~N}\right)_{\text {tissue }}=$ atom percent ${ }^{15} \mathrm{~N}$ in the plant tissue $\left(\right.$ atom $\left.\%{ }^{15} \mathrm{~N}\right)$. $=$ atom percent ${ }^{15} \mathrm{~N}$ of the fertilizer applied, and $\mathrm{NDFF}={ }^{15} \mathrm{~N}$ in the plant derived from applied fertilizer ${ }^{15} \mathrm{~N}$.

NDFF is a direct measure of actual fertilizer $\mathrm{N}$ uptake and does not include $\mathrm{N}$ from nonfertilizer sources. Fertilizer N uptake efficiency is then calculated as (NDFF/ $\left.\mathrm{F}^{15} \mathrm{NA}\right)$ $\times 100=$ fertilizer $\mathrm{N}$ uptake efficiency, where $\mathrm{NDFF}={ }^{15} \mathrm{~N}$ in the plant derived from applied fertilizer ${ }^{15} \mathrm{~N}$ and $\mathrm{F}^{15} \mathrm{NA}=$ the amount of fertilizer ${ }^{15} \mathrm{~N}$ applied.

In containers, the fertilizer ${ }^{15} \mathrm{~N}$ tracer method offers two advantages over the total $\mathrm{N}$ method of determining fertilizer $\mathrm{N}$ uptake and fertilizer $\mathrm{N}$ uptake efficiency. It eliminates the assumption that total $\mathrm{N}$ uptake is primarily due to fertilizer $\mathrm{N}$, and it distinguishes fertilizer $\mathrm{N}$ from nonfertilizer N. However, the fertilizer ${ }^{15} \mathrm{~N}$ tracer method underestimates fertilizer $\mathrm{N}$ uptake when applied fertilizer ${ }^{15} \mathrm{~N}$ is immobilized in substrate organic matter and nonlabeled substrate $\mathrm{N}$ is released for plant uptake (pool substitution; Hart et al., 1986; Jansson and Persson, 1982; Walters and Malzer, 1990).

Nonisotopic determination of fertilizer $\mathrm{N}$ uptake is consistently higher than isotopic determination (Hauck, 1978; Walters and Malzer, 1990; Westerman and Kurtz, 1974). $\mathrm{N}$ from nonfertilizer sources causes the nonisotopic method to overestimate the uptake of fertilizer N (Bronson et al., 2000; Olson, 1980; Oslon and Swallow, 1984; Rao et al., 1991; Westerman and Kurtz, 1974). The addition of fertilizer $\mathrm{N}$ may increase the mineralization, availability, and plant uptake of native soil $\mathrm{N}$ (Azam et al., 1989; Chalk et al., 1990; Hart et al., 1986; Jenkinson et al., 1985; Wood et al., 1987). Similarly, added ${ }^{15} \mathrm{~N}$ may be exchanged for unlabeled $\mathrm{N}$ in the soil organic matter, thus some of the fertilizer dependent increases in total $\mathrm{N}$ will not be revealed with an analysis of the ${ }^{15} \mathrm{~N}$ in plant tissues (Jansson and Persson, 1982; Walters and Malzer, 1990). These factors may explain differences between the two approaches.

The objectives of this study were 1) to determine the effect of $\mathrm{N}$ rate on the growth and $\mathrm{N}$ status of three container-grown woody ornamentals, 2) to determine if the total $\mathrm{N}$ method and fertilizer ${ }^{15} \mathrm{~N}$ tracer method produce different estimates of fertilizer $\mathrm{N}$ uptake and fertilizer $\mathrm{N}$ uptake efficiency in containergrown plants, 3 ) to determine the effect of $\mathrm{N}$ rate on estimation of fertilizer $\mathrm{N}$ uptake and fertilizer $\mathrm{N}$ uptake efficiency by the total $\mathrm{N}$ method and fertilizer ${ }^{15} \mathrm{~N}$ tracer method, and 4) to determine the cause of the inconsistency between the two methods. This investigation is not an $\mathrm{N}$ balance study that seeks to account for all $\mathrm{N}$ in the growing system. Instead, the work described herein focuses on the measurement of $\mathrm{N}$ uptake and $\mathrm{N}$ uptake efficiency in container growing systems. 


\section{Materials and Methods}

On 1 Apr. 2001, uniform rooted cuttings of Euonymus alatus (Thunb.) Sieb., E. alatus 'Compactus', Cornus sericea L. 'Cardinal', $C$. sericea 'Isanti', Weigelaflorida (Bunge)A.DC. 'Red Prince', and W.florida 'Alexandra' (Wine and Roses) were potted into 3.8-L containers. At planting, 10 plants of each taxon were partitioned into shoots and roots, dried, weighed, ground to pass a $0.85-\mathrm{mm}$ sieve, and analyzed for total $\mathrm{N}$ by the Kjeldahl procedure (Horneck et al., 1989). These data were subtracted from final measurements of dry weight and plant $\mathrm{N}$ to determine growth and $\mathrm{N}$ uptake during the experimental period.

Euonymus alatus represented a slow growing species while $W$. florida and $C$. sericea represented fast growing species. Within each species there was one taxon with dwarf characteristics and one taxon with nondwarf or standard growth characteristics. Within $E$. alatus, the species represented the nondwarftype while 'Compactus' represented the dwarf type. Within W. florida, 'Red Prince' represented the nondwarf type while 'Alexandra' represented the dwarf type. Within C. sericea, 'Cardinal' represented the nondwarf type while 'Isanti' represented the dwarf type.

The growing substrate consisted of 7 fresh douglas fir [Pseudotsuga menziesii (Mirb.) Franco.] bark (initial pH of 3.6) : 2 sphagnum peatmoss : 1 silica sand $(0.65 \mathrm{~mm})$, by volume. The substrate was amended with $0.883 \mathrm{~kg}$ Micromax (The Scotts Co., Marysville, Ohio), 1.77 $\mathrm{kg}$ ag lime $\left(\mathrm{CaCO}_{3}\right), 1.77 \mathrm{~kg}$ dolomite $\left(\mathrm{CaCO}_{3}\right.$ $\left.+\mathrm{MgCO}_{3}\right), 1.05 \mathrm{~kg} 8$ to 9 month slow-release $\mathrm{P}$ (The Scotts Co.), and $1.18 \mathrm{~kg} 8$ to 9 month slow-release K (The Scotts Co.) all per $\mathrm{m}^{3}$. Substrate $\mathrm{pH}$ at transplanting (after all amendments were added) was 5.6.

Experiments were conducted outdoors in full sun on a gravel pad at Oregon State University's Lewis Brown Horticulture Farm (Corvallis, Ore.; latitude: 44.5 north, longitude: 123.2 west) in a completely randomized design with four replications per treatment. Water from the horticulture farm had a $\mathrm{NO}_{3}^{-}$concentration of $4.54 \mathrm{mg} \cdot \mathrm{L}^{-1}$.

Treatments consisted of five $\mathrm{N}$ application rates (NAR): 25, 50 100, 200, and 300 $\mathrm{mg} \cdot \mathrm{L}^{-1}$ delivered as aqueous, double-labeled ${ }^{15} \mathrm{~N}$ depleted $\mathrm{NH}_{4} \mathrm{NO}_{3}\left(\min 99.95 \%\right.$ atom ${ }^{14} \mathrm{~N}$; Isotec, Miamisburg, Ohio). The amounts of $\mathrm{N}$ delivered to each container over the duration of the study at NARs of 25, 50100,200 , and 300 $\mathrm{mg} \cdot \mathrm{L}^{-1}$ were $307,615,1230,2460$, and 3690 $\mathrm{mg}$, respectively. Treatments began on 9 Apr., and were applied on alternate days until 9 Sept. At each application, each container received the same N solution volume. During the first two months of the experiment, treatments were applied with a Wheaton Unispense Peristaltic Pump (Wheaton Science Products, Millville N.J.), while volumes were low, and were later applied with $354.8 \mathrm{ml}$ plastic bottles modified to fill and drain to the required amount. From 9 Apr. to 18 May, plants received 100,150,200, or $250 \mathrm{~mL}$ of fertilizer solution at each treatment. From 22 May to 10 Sept. plants received $300 \mathrm{~mL}$ of fertilizer solution at each treatment. After 16 June, supplemental irrigation was delivered on days when the plants did not receive treatments. Overhead irrigation rates began at $300 \mathrm{~mL} \cdot \mathrm{d}^{-1}$ per container and reached $500 \mathrm{~mL} \cdot \mathrm{d}^{-1}$ per container by 9 Sept. when treatments and irrigation were ended. Supplemental irrigation rates were adjusted to maintain a $25 \%$ leaching fraction at each $\mathrm{N}$ solution application throughout the experiment and monitored weekly.

Plants were harvested dormant (after total leaf-fall but before spring growth; 11 Mar. 2002) to avoid sampling during periods of high $\mathrm{N}$ flux. Three replications from each taxon and NAR were destructively harvested and partitioned into roots and shoots. Potting substrate was removed from the root system with a high-pressure hose nozzle. All tissues were dried, weighed, and ground to pass a $0.425-\mathrm{mm}$ sieve. Total $\mathrm{N}$ was determined by mass spectrometry at Isotope Services (Los Alamos N.M.). Fertilizer N uptake and fertilizer $\mathrm{N}$ uptake efficiency were calculated by the total $\mathrm{N}$ method and fertilizer $\mathrm{N}$ tracer method (see Introduction for equations). Data were analyzed as a completely randomized design and regression analyses were performed with SAS v. 8.02 (SAS Institute, Cary, N.C.).

\section{Results and Discussion}

Weigela florida 'Red Prince' is described as upright, growing to $1.8 \mathrm{~m}$, and $W$. florida
'Alexandra' (Wine and Roses) is described as a compact shrub growing $1.2 \mathrm{~m}$ high and wide (Dirr, 1998). However, in the present study there was no significant difference in dry weight or $\mathrm{N}$ content of the two cultivars. Likewise, E. alatus and the cultivar 'Compactus' are described as 4.6 to $6.1 \mathrm{~m}$ and 3.1 $\mathrm{m}$ tall and wide, respectively (Dirr, 1998). Yet, after 1 year of container production from rooted cuttings, the taxa were similar in size and habit, and their dry weight and $\mathrm{N}$ content were not significantly different. Cornus sericea 'Cardinal' was upright in habit with one to three dominant leaders while $C$. sericea 'Isanti' was lower growing and more heavily branched. Though $C$. sericea 'Cardinal' and C. sericea 'Isanti' have different growth habits and are described as growing to 3.1 and $1.8 \mathrm{~m}$ tall, respectively (Dirr, 1998), their dry weight and $\mathrm{N}$ content were not significantly different. Consequently, dry weight and $\mathrm{N}$ content data were pooled within each species.

Growth and $N$ status. Root dry weight (RDW), shoot dry weight (SDW), and total plant dry weight (TDW) increased for all species as $\mathrm{N}$ application rates (NARs) increased from 25 to $300 \mathrm{mg} \cdot \mathrm{L}^{-1}$ (Table 1). Studies at comparable NARs have reported an increase in plant dry weight from $0 \mathrm{mg} \cdot \mathrm{L}^{-1}$ followed by a plateau at higher NARs (Griffin et al., 1999). Other studies have reported negative effects on growth at NARs beyond 50 or $60 \mathrm{mg} \cdot \mathrm{L}^{-1}$ for some container-grown plants when fertilizer solutions are applied at every irrigation (Barnett and Ormrod, 1985; Cabrera, 2003; Cabrera and Devereaux, 1998), and the reduction in growth has been attributed to high substrate salinity (Cabrera and Devereaux, 1998). In the present study, it is logical that supplemental irrigation applied between $\mathrm{N}$ solutions served to flush the containers and prevent the increase of substrate salinity to harmful levels. Similar to other studies (Cabrera, 2003; Cabrera and Devereaux, 1998), root to shoot (R:S) ratios were higher at low NARs and decreased with increasing NARs (Table 1). At each NAR, TDW was greatest for $C$. sericea and least for E. alatus (Table 1). Root N (RN), shoot N (SN), and total plant $\mathrm{N}(\mathrm{TN})$ increased with increasing NARs (Table 2). For each taxon at each NAR, more $\mathrm{N}$ was stored in the roots

Table 1. Root dry weight (RDW), shoot dry weight (SDW), total plant dry weight (TDW), and root to shoot ratio (R:S) of 11-month-old ${ }^{z}$ container-grown Cornus sericea, Weigela florida, and Euonymus alatus grown at $\mathrm{N}$ application rates (NARs) of 25, 50, 100, 200, and $300 \mathrm{mg} \cdot \mathrm{L}^{-1}$.

\begin{tabular}{|c|c|c|c|c|c|c|c|c|c|c|c|c|}
\hline \multirow[b]{3}{*}{$\begin{array}{l}\text { NAR } \\
\left(\mathrm{mg} \cdot \mathrm{L}^{-1}\right)\end{array}$} & \multicolumn{12}{|c|}{ Plant taxon } \\
\hline & \multicolumn{4}{|c|}{ Cornus sericea } & \multicolumn{4}{|c|}{ Weigela florida } & \multicolumn{4}{|c|}{ Euonymus alatus } \\
\hline & $\begin{array}{c}\text { RDW } \\
(\mathrm{g})\end{array}$ & $\begin{array}{c}\text { SDW } \\
(\mathrm{g})\end{array}$ & $\begin{array}{c}\text { TDW } \\
(\mathrm{g})\end{array}$ & $\mathrm{R}: \mathrm{S}$ & $\begin{array}{c}\text { RDW } \\
(\mathrm{g})\end{array}$ & $\begin{array}{c}\text { SDW } \\
(\mathrm{g})\end{array}$ & $\begin{array}{c}\text { TDW } \\
(\mathrm{g})\end{array}$ & $\mathrm{R}: \mathrm{S}$ & $\begin{array}{c}\text { RDW } \\
(\mathrm{g})\end{array}$ & $\begin{array}{c}\text { SDW } \\
(\mathrm{g})\end{array}$ & $\begin{array}{l}\text { TDW } \\
(\mathrm{g})\end{array}$ & $\mathrm{R}: \mathrm{S}$ \\
\hline 25 & $16.1^{\mathrm{y}}$ & 5.4 & 21.5 & 3.5 & 9.6 & 4.2 & 13.7 & 2.3 & 3.0 & 1.1 & 4.2 & 3.2 \\
\hline 50 & 23.3 & 14.8 & 38.1 & 1.7 & 17.4 & 8.3 & 25.7 & 2.1 & 4.6 & 2.8 & 7.4 & 1.7 \\
\hline 100 & 30.6 & 27.7 & 58.3 & 1.2 & 22.7 & 16.8 & 39.5 & 1.4 & 5.0 & 2.2 & 7.1 & 2.2 \\
\hline 200 & 34.1 & 35.4 & 69.5 & 1.1 & 25.3 & 22.8 & 48.1 & 1.1 & 8.7 & 5.9 & 14.5 & 1.5 \\
\hline 300 & 47.2 & 42.5 & 89.8 & 1.2 & 24.4 & 24.4 & 48.9 & 1.0 & 9.4 & 7.4 & 16.8 & 1.3 \\
\hline Linear $^{\mathrm{x}}$ & $* * *$ & $* * *$ & $* * *$ & $* *$ & $* * *$ & $* * *$ & $* * *$ & $* * *$ & $* * *$ & $* * *$ & $* * *$ & $* *$ \\
\hline$r^{2}$ & 0.76 & 0.61 & 0.73 & 0.29 & 0.47 & 0.81 & 0.69 & 0.70 & 0.45 & 0.62 & 0.54 & 0.22 \\
\hline Quadratic & $* * *$ & $* * *$ & $* * *$ & $* * *$ & $* * *$ & $* * *$ & $* * *$ & $* * *$ & $* * *$ & $* * *$ & $* * *$ & $*$ \\
\hline$r^{2}$ & 0.76 & 0.67 & 0.76 & 0.51 & 0.69 & 0.92 & 0.86 & 0.84 & 0.46 & 0.62 & 0.55 & 0.24 \\
\hline
\end{tabular}

${ }^{2}$ Data collected 11 Mar. 2002 before spring growth.

${ }^{y}$ All values are means of six single-plant replications.

${ }^{x}$ Significance and $r^{2}$ values for the linear and quadratic models were calculated using all data points (not only the means) and represent the full model in each case (not single terms).

Ns, ${ }^{* * * *, * * *}$ Nonsignificant or significant at $P \leq 0.05,0.01$, or 0.001 respectively. 
Table 2. Root nitrogen (RN), shoot nitrogen (SN), total plant nitrogen (TN), and average whole plant nitrogen concentration (\%N) of 11-month-old ${ }^{z}$ containergrown Cornus sericea, Weigela florida, and Euonymus alatus. Plants were grown at $\mathrm{N}$ application rates (NARs) of 25, 50, 100, 200, and $300 \mathrm{mg} \cdot \mathrm{L}^{-1}$.

\begin{tabular}{|c|c|c|c|c|c|c|c|c|c|c|c|c|}
\hline \multirow[b]{3}{*}{$\begin{array}{l}\text { NAR } \\
\left(\mathrm{mg} \cdot \mathrm{L}^{-1}\right)\end{array}$} & \multicolumn{12}{|c|}{ Plant taxon } \\
\hline & \multicolumn{4}{|c|}{ Cornus sericea } & \multicolumn{4}{|c|}{ Weigela florida } & \multicolumn{4}{|c|}{ Euonymus alatus } \\
\hline & $\begin{array}{c}\mathrm{RN} \\
(\mathrm{mg})\end{array}$ & $\begin{array}{c}\mathrm{SN} \\
(\mathrm{mg})\end{array}$ & $\begin{array}{c}\mathrm{TN} \\
(\mathrm{mg})\end{array}$ & $\% \mathrm{~N}$ & $\begin{array}{l}\mathrm{RN} \\
(\mathrm{mg})\end{array}$ & $\begin{array}{c}\mathrm{SN} \\
(\mathrm{mg})\end{array}$ & $\begin{array}{c}\mathrm{TN} \\
(\mathrm{mg})\end{array}$ & $\% \mathrm{~N}$ & $\begin{array}{c}\mathrm{RN} \\
(\mathrm{mg})\end{array}$ & $\begin{array}{c}\mathrm{SN} \\
(\mathrm{mg})\end{array}$ & $\begin{array}{c}\mathrm{TN} \\
(\mathrm{mg})\end{array}$ & $\% \mathrm{~N}$ \\
\hline 25 & 146.7 & 44.4 & 191.2 & 0.91 & 182.7 & 69.8 & 252.4 & 1.84 & 60.7 & 19.3 & 80.1 & 2.0 \\
\hline 50 & 193.3 & 106.1 & 299.4 & 0.8 & 296.1 & 110.6 & 406.7 & 1.59 & 83.9 & 41.1 & 124.9 & 1.7 \\
\hline 100 & 272.5 & 202.9 & 475.4 & 0.83 & 438.8 & 254.6 & 693.4 & 1.8 & 118.1 & 40.3 & 158.4 & 2.5 \\
\hline 200 & 431.7 & 279.0 & 710.7 & 1.1 & 575.0 & 399.2 & 974.2 & 2.1 & 201.4 & 105.7 & 307.1 & 2.1 \\
\hline 300 & 632.7 & 363.9 & 996.6 & 1.2 & 596.6 & 445.8 & 1042.4 & 2.1 & 217.9 & 129.3 & 347.2 & 2.1 \\
\hline Linear $^{x}$ & $* * *$ & $* * *$ & $* * *$ & $* *$ & $* * *$ & $* * *$ & $* * *$ & $* * *$ & $* * *$ & $* * *$ & $* * *$ & NS \\
\hline$r^{2}$ & 0.91 & 0.82 & 0.96 & 0.32 & 0.78 & 0.87 & 0.85 & 0.40 & 0.55 & 0.65 & 0.65 & 0.02 \\
\hline Quadratic & $* * *$ & $* * *$ & $* * *$ & $* *$ & $* * *$ & $* * *$ & $* * *$ & $* * *$ & $* * *$ & $* * *$ & $* * *$ & NS \\
\hline$r^{2}$ & 0.91 & 0.85 & 0.96 & 0.32 & 0.91 & 0.93 & 0.95 & 0.40 & 0.57 & 0.65 & 0.66 & 0.08 \\
\hline
\end{tabular}

${ }^{2}$ Data collected 11 Mar. 2002 before spring growth.

${ }^{y}$ All values are means of six single-plant replicates.

${ }^{x}$ Significance and $r^{2}$ values for the linear and quadratic models were calculated using all data points (not only the means) and represent the full model in each case (not single terms).

Ns,****,***NNonsignificant or significant at $P \leq 0.05,0.01$, or 0.001 respectively.

than in the shoots (Table 2). TDW and TN of $W$. florida displayed the strongest quadratic response to NAR among the three species.
The responses of C.sericea and E. alatus were best described by linear models. Despite having lower TDW at each NAR (Table 1), $W$.
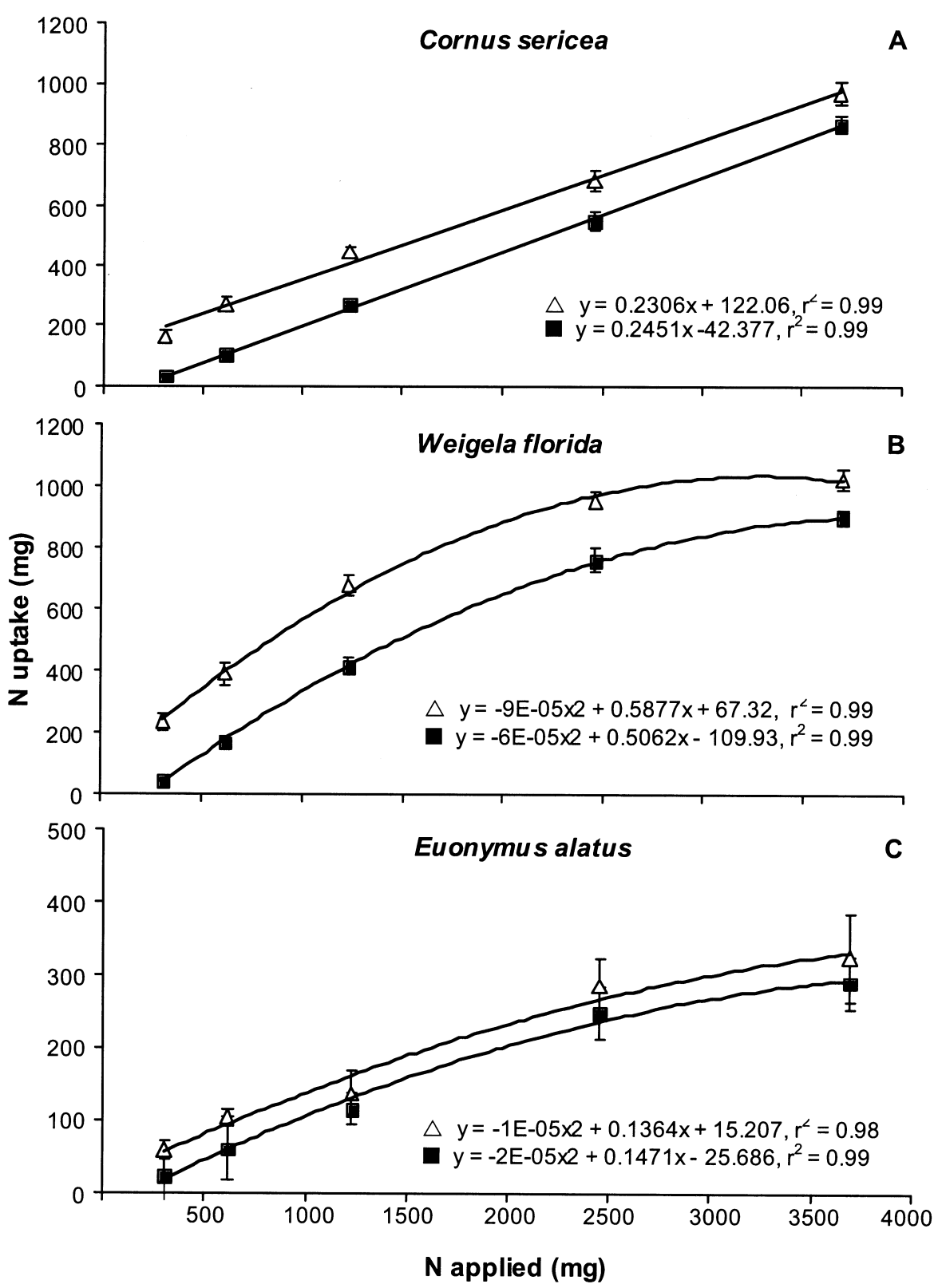

florida had higher TN than C.sericea at each NAR (Table 2) because the average whole plant $\mathrm{N}$ concentration $(\% \mathrm{~N})$ was consistently higher for $W$. florida than for C.sericea at all NARs (Table 2).

Nuptake. For each species, TNG and NDFF calculated by the total $\mathrm{N}$ method and fertilizer tracer method, respectively, increased as NARs increased from 25 to $300 \mathrm{mg} \cdot \mathrm{L}^{-1}$; however, TNG was higher than NDFF for all species at each NAR (Fig. 1). The difference between the two estimates may be attributed to the inclusion of nonfertilizer $\mathrm{N}$ sources (e.g., irrigation water, mineralization from the substrate) in the total $\mathrm{N}$ method and the underestimation of fertilizer $\mathrm{N}$ uptake by the ${ }^{15} \mathrm{~N}$ fertilizer $\mathrm{N}$ tracer method.

Because the total $\mathrm{N}$ method of determining $\mathrm{N}$ uptake does not distinguish between fertilizer and nonfertilizer N, TNG includes $\mathrm{N}$ derived from nonfertilizer sources. This causes a positive y intercept for $\mathrm{N}$ uptake at 0 $\mathrm{NAR}$, despite the fact that no fertilizer $\mathrm{N}$ was applied or absorbed. Agronomist routinely account for this problem by using the difference method to determine $\mathrm{N}$ recovery in field-grown agronomic crops. The amount of $\mathrm{N}$ in unfertilized plants is subtracted from the amount of $\mathrm{N}$ in fertilized plants producing an estimate of the amount of $\mathrm{N}$ derived from the fertilizer. Unfortunately, this method is not suitable for long-term container-grown nursery crop studies because the potting substrate supplies insufficient $\mathrm{N}$ to sustain woody crops for a typical growing season.

The water used to mix treatment solutions and the supplemental irrigation water had an $\mathrm{NO}_{3}$ concentration of $4.54 \mathrm{mg} \cdot \mathrm{L}^{-1}$. During the experimental period, each plant received a total of $28 \mathrm{~L}$ of water in treatment solutions

Fig. 1. Nitrogen (N) gain of (A) Cornus sericea, (B) Weigela florida, and (C) Euonymus alatus determined by $(\Delta)$ the total $\mathrm{N}$ method [total $\mathrm{N}$ in the plant at the end of the experiment - total $\mathrm{N}$ in the cutting before $\mathrm{N}$ treatments $=$ total $\mathrm{N}$ gain $(\mathrm{TNG})]$ and $(\square)$ a ${ }^{15} \mathrm{~N}$ fertilizer tracer $[\mathrm{N}$ derived from fertilizer (NDFF)]. Plants were grown for 11 months in 3.8-L containers at $\mathrm{N}$ concentrations of $25,50,100,200$, and 300 $\mathrm{mg} \cdot \mathrm{L}^{-1}$. Error bars indicate $\pm \mathrm{SE}$. 
or supplemental irrigation. Considering that $\mathrm{NO}_{3}$ is $22 \% \mathrm{~N}$, the combined solution and irrigation water had the potential to supply $28 \mathrm{mg}$ of nonfertilizer $\mathrm{N}$ to each container over the duration of the experiment. Douglas fir bark and sphagnum peatmoss are about $0.12 \%$ and $0.83 \% \mathrm{~N}$ respectively (Bollen,

Fig. 2. Fertilizer nitrogen (N) uptake efficiency of (A) Cornus sericea, (B) Weigela florida, and (C) Euonymus alatus determined by $(\Delta)$ the total $\mathrm{N}$ method [(total $\mathrm{N}$ in the plant at the end of the experiment - total $\mathrm{N}$ in the cutting before $\mathrm{N}$ treatments $) /($ applied fertilizer $\mathrm{N}) \times 100]$ and (西) with a ${ }^{15} \mathrm{~N}$ fertilizer tracer $\left[\left(\right.\right.$ total ${ }^{15} \mathrm{~N}$ in the plant $) /\left({ }^{15} \mathrm{~N}\right.$ applied $\left.) \times 100\right]$. A corrected $(\bullet)$ uptake efficiency that accounts for the underestimation of ${ }^{15} \mathrm{~N}$ uptake is also shown. The differences between the y intercepts for ${ }^{15} \mathrm{~N}$ uptake regression lines and their origins (Fig.1) were added to each data point before calculating the corrected uptake efficiency for each species. Plants were grown for 11 months in 3.8 L containers at $\mathrm{N}$ concentrations of $25,50,100,200$, and $300 \mathrm{mg} \cdot \mathrm{L}^{-1}$. Error bars indicate $\pm \mathrm{SE}$.
1969). Therefore, $0.7 \mathrm{~kg}$ of douglas fir bark (amount in each 3.8-L container) at $0.12 \% \mathrm{~N}$ contains $840 \mathrm{mg}$ of organic N. Likewise, 0.1 $\mathrm{kg}$ of sphagnum peatmoss (amount in each 3.8 $\mathrm{L}$ container) at $0.83 \% \mathrm{~N}$ contains $830 \mathrm{mg}$ of organic N. The substrate and irrigation water had the potential to supply $1698 \mathrm{mg}$ of nonfertilizer $\mathrm{N}$ to each plant. The actual amount used by the plant would be dependent upon environmental conditions, mineralization rates, and plant uptake. Mineralization of a portion of the $1698 \mathrm{mg}$ of $\mathrm{N}$ could account for the nonfertilizer $\mathrm{N}$ represented by the positive $\mathrm{y}$ intercept at 0 NAR.

The inclusion of nonfertilizer sources resulted in TNG values that were greater than actual fertilizer $\mathrm{N}$ uptake at all NARs (Fig. 1). At high NARs, nonfertilizer sources are a relatively small portion of total plant $\mathrm{N}$, but at low NARs, they account for a majority of total plant N. This agrees with the findings of Azam et al. (1991) who demonstrated that soil $\mathrm{N}$ was a significant portion of total plant $\mathrm{N}$ of wetland rice produced at low fertilizer $\mathrm{N}$ rates.
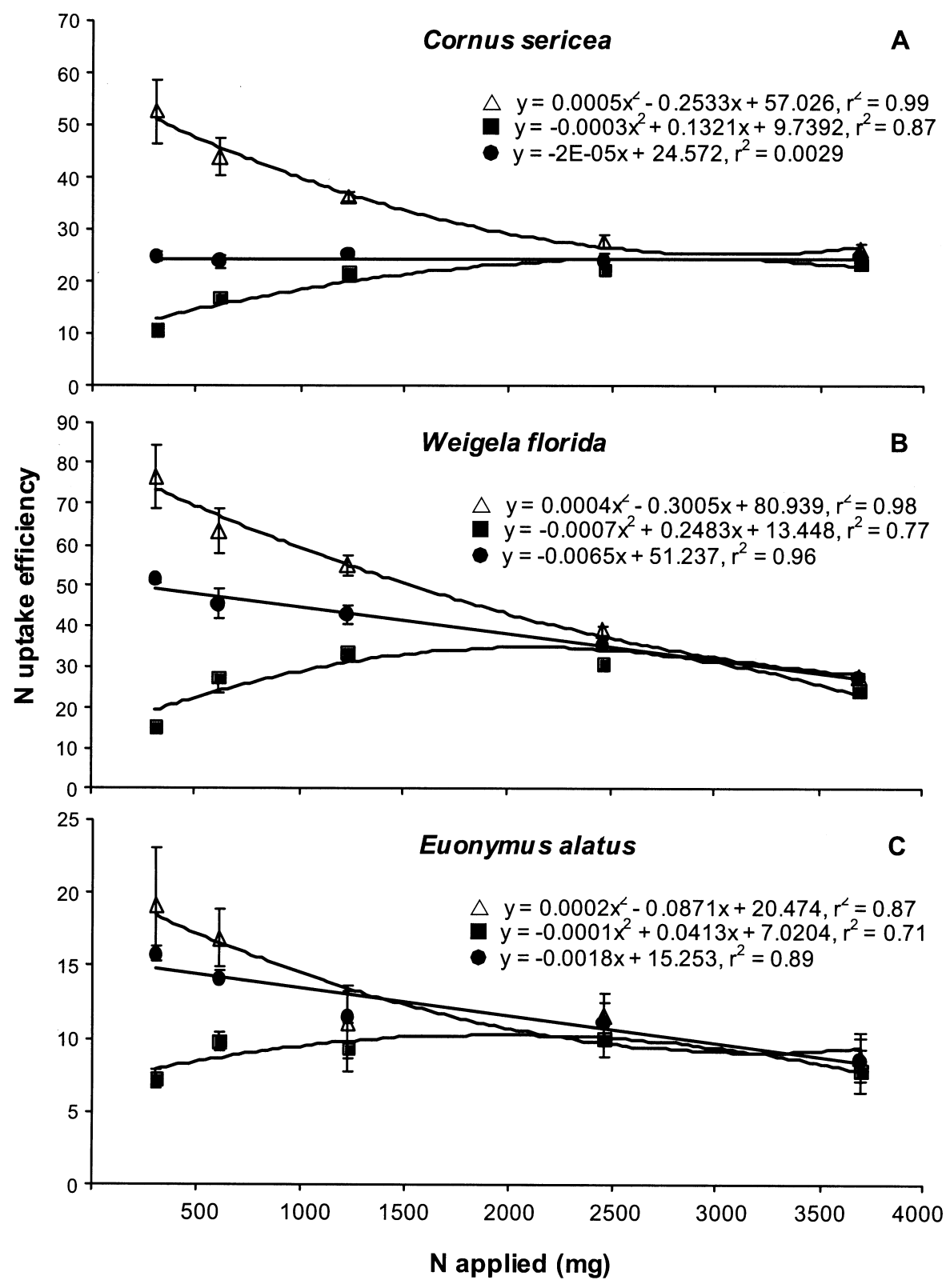

Fertilizer $\mathrm{N}$ uptake is often underestimated by the ${ }^{15} \mathrm{~N}$ fertilizer $\mathrm{N}$ tracer method (Hart et al., 1986; Jansson and Persson, 1982; Walters and Malzer, 1990). This causes a negative y intercept for ${ }^{15} \mathrm{~N}$ uptake at $0 \mathrm{NAR}$, despite the fact that it would be impossible for plants to contain a negative amount of ${ }^{15} \mathrm{~N}$ at 0 NAR (Fig. 1). Applied fertilizer ${ }^{15} \mathrm{~N}$ may be immobilized and incorporated in substrate organic matter. Simultaneously, nonlabeled substrate $\mathrm{N}$ may be released and become available for plant uptake. The substitution of unlabeled nonfertilizer $\mathrm{N}$ (pool substitution) from the substrate for applied fertilizer ${ }^{15} \mathrm{~N}$ (Hart et al., 1986, Rao et al., 1991) can cause underestimation of fertilizer $\mathrm{N}$ uptake.

$N$ uptake efficiency. Fertilizer $\mathrm{N}$ uptake efficiency determined by the total $\mathrm{N}$ method was highest at $25 \mathrm{mg} \cdot \mathrm{L}^{-1}$ and decreased as NARs increased (Fig. 2). In contrast, fertilizer $\mathrm{N}$ uptake efficiency determined by the ${ }^{15} \mathrm{~N}$ fertilizer tracer method increased at low NARs and then leveled off ( $C$. sericea) or decreased slightly ( $W$. florida and E. alatus; Fig. 2). The inclusion of nonfertilizer $\mathrm{N}$ sources as part of the TNG term in the numerator caused the total $\mathrm{N}$ method to overestimate $\mathrm{N}$ fertilizer uptake efficiency. The exclusion of the immobilized ${ }^{15} \mathrm{~N}$ as part of the NDFF term in the numerator caused the ${ }^{15} \mathrm{~N}$ fertilizer tracer method to underestimate $\mathrm{N}$ fertilizer uptake efficiency. At low NARs, the overestimate caused by the total $\mathrm{N}$ method and the underestimate caused by the ${ }^{15} \mathrm{~N}$ fertilizer tracer method are larger portions of total plant $\mathrm{N}$ and NAR. Therefore, the difference in estimation of $\mathrm{N}$ uptake efficiency between each method was larger at low NARs for all species (Fig. 2). At high NARs, the overestimate caused by the total $\mathrm{N}$ method and the underestimate caused by the ${ }^{15} \mathrm{~N}$ fertilizer tracer method were a smaller portion of total plant $\mathrm{N}$, and the two methods produced similar estimates (Fig. 2).

The efficiency curves calculated by the total $\mathrm{N}$ method and the ${ }^{15} \mathrm{~N}$ fertilizer tracer method (Fig. 2) do not represent actual $\mathrm{N}$ uptake efficiency because they are calculated from $\mathrm{N}$ uptake curves that do not pass through the origin at 0 NAR. This is in agreement with others who have concluded that calculations of photosynthetic nitrogen use efficiency based on nonzero intercepts are erroneous (Meinzer andZhu, 1998; Ranjith and Meinzer, 1997; Sage and Pearcy, 1987). The conclusion is further supported by an evaluation of the $\mathrm{N}$ uptake curves in Fig. 1. For C. sericea, equations for estimating $\mathrm{N}$ uptake by the total $\mathrm{N}$ and ${ }^{15} \mathrm{~N}$ fertilizer tracer methods produce linear lines with similar slopes (Fig. 1A). Therefore, across the range of NARs the incremental increase in $\mathrm{N}$ uptake for both methods is constant, i.e., for every $\mathrm{mg}$ of $\mathrm{N}$ applied, $0.23 \mathrm{mg}$ of total $\mathrm{N}$ or $0.24 \mathrm{mg}$ of ${ }^{15} \mathrm{~N}$ is absorbed (Fig. 1 A, slopes). The rate of change (derivative) of all linear functions is a constant (Newton, 1687). For $W$. florida and E. alatus the equations for estimating $\mathrm{N}$ uptake by the total $\mathrm{N}$ and ${ }^{15} \mathrm{~N}$ fertilizer tracer methods produce 2 nd degree polynomial lines (Fig. 1B and C). Therefore, across the range of NARs, the incremental increase in $\mathrm{N}$ uptake for both methods is declining. The rate 
of change (derivative) for 2 nd degree polynomial functions must be a linear function with a negative slope (Newton, 1687).

The constant efficiency for $C$. sericea was estimated by adding the difference between the y intercept for the ${ }^{15} \mathrm{~N}$ uptake regression line and the origin (Fig. 1A) to each data point before calculating ${ }^{15} \mathrm{~N}$ uptake efficiency. A linear regression was fitted to the corrected data to produce the corrected fertilizer $\mathrm{N}$ uptake efficiency shown in Fig. 2A.

A linearly declining efficiency for $W$. florida and E. alatus was estimated by adding the difference between the y intercepts for their ${ }^{15} \mathrm{~N}$ uptake regression lines and the origins (Fig. 1 B and C) to each data point before calculating ${ }^{15} \mathrm{~N}$ uptake efficiency. The adjusted data produced the corrected fertilizer $\mathrm{N}$ uptake efficiencies shown in Fig. 2B and C. Similar corrected efficiency equations $(\mathrm{y}=0.001 \mathrm{x}+0.195, \mathrm{y}=$ $0.003+40.607$ and $\mathrm{y}=0.002 \mathrm{x}+15.3$ for $C$. sericea, W. florida and E. alatus, respectively) can be derived by subtracting the difference between the y intercepts for the total $\mathrm{N}$ method regression lines and the origins (Fig. 1) to each total $\mathrm{N}$ data point before recalculating total $\mathrm{N}$ uptake efficiency. A constant linear efficiency across NARs of 25 to $300 \mathrm{mg} \cdot \mathrm{L}^{-1}$ indicates that $C$. sericea plants developed the capacity to take up $\mathrm{N}$ at a rate constant relative to the increase in NAR. In contrast, a declining linear efficiency across NARs of 25 to $300 \mathrm{mg} \cdot \mathrm{L}^{-1}$ indicates that for $W$. florida and E. alatus the capacity to take up $\mathrm{N}$ did not develop at the same relative rate as increases in NAR.

Since nonfertilizer sources contribute to total N uptake in plants grown in soilless substrate (Fig. 1), total N estimates that do not account for nonfertilizer sources can overestimate N uptake efficiency. By-difference estimates are routinely done in agronomic applications (Hauck, 1978; Walters and Malzer, 1990; Westerman and Kurtz, 1974) and should also be applied to soilless substrates. The underestimation of $\mathrm{N}$ uptake efficiency with ${ }^{15} \mathrm{~N}$ approaches can also be avoided as we describe here. However, in much of the literature this has not been done (Jansson and Persson, 1982; Rao et al., 1991; Walters and Malzer, 1990). Corrected total N approaches are often compared to uncorrected ${ }^{15} \mathrm{~N}$ based assessments (Jansson and Persson, 1982; Rao et al., 1991; Walters and Malzer, 1990). If a correction of both approaches were made discrepancies would likely be less than what is commonly observed.

\section{Conclusions}

In all species, root, shoot, and total dry weight increased with increasing NARs while root to shoot ratios decreased. Similarly, root, shoot, and total plant $\mathrm{N}$ increased with NAR for each species, and at each NAR more $\mathrm{N}$ was stored in the roots than in the shoots. Estimation of fertilizer N uptake determined by the total $\mathrm{N}$ method was higher for all species and at each NAR than estimation of $\mathrm{N}$ uptake determined by the fertilizer ${ }^{15} \mathrm{~N}$ tracer method. The total
$\mathrm{N}$ method and ${ }^{15} \mathrm{~N}$ fertilizer tracer method overestimate and underestimate, respectively, fertilizer $\mathrm{N}$ uptake. Consequently, fertilizer $\mathrm{N}$ uptake efficiency in container grown plants is also over- and underestimated, and the error is accentuated at low NARs. Corrected N uptake efficiency values can be calculated by adjusting the original data (total $\mathrm{N}$ or ${ }^{15} \mathrm{~N}$ uptake) by the distance between the origin and the y intercept of the regression line representing the data.

\section{Literature Cited}

Azam, F., F.J. Stevenson, and R.L. Mulvaney. 1989. Chemical extraction of newly immobilized ${ }^{15} \mathrm{~N}$ and native soil $\mathrm{N}$ as influenced by substrate addition rate and soil treatments. Soil Biol. Biochem. 21:715-722.

Azam, F., M. Ashraf, A. Lodhi, and M.I. Sajjad. 1991. Relative significance of soil and nitrogenous fertilizer in nitrogen nutrition and growth of wetland rice (Oryza sativa L.). Biol. Fert. Soils 11:57-61.

Barnett, C.E. and D.P. Ormrod. 1985. Responses of Tilia cordata and Acer platanoides in pots to nitrogen levels. HortScience 20:283-285.

Bollen, W.B. 1969. Properties of tree bark in relation to their agricultural utilization. USDA For. Serv. Res. Paper PNW-77.

Bronson, K.F., F. Hussain, E. Pasuquin, and J.K. Ladha. 2000. Use of ${ }^{15} \mathrm{~N}$-labeled soil in measuring nitrogen fertilizer recovery efficiency in transplanted rice. Soil Sci. Soc. Amer. J. 64:235-239.

Bunt, A.C. 1988. Media mixes for container-grown plants. Unwin Hyman, London.

Cabrera, R.I. 2003. Nitrogen balance for two container-grown woody ornamental plants. Scientia Hort. 97:297-308.

Cabrera, R.I. and D.R. Devereaux. 1998. Effects of nitrogen supply on growth and nutrient status of containerized crape myrtle. J. Environ. Hort. 16:98-104.

Chalk, P.M., R.L. Victoria, T. Muraoka, and M.C. Piccolo. 1990. Effect of nitrification inhibitor on immobilization and mineralization of soil and fertilizer nitrogen. Soil Biol. Biochem. 22:533-538.

Dirr, M.A. 1998. Manual of woody landscape plants: Their identification, ornamental characteristics, culture, propagation and uses. 5th ed. Stipes, Champaign, Ill.

Griffin, J.J., S.L. Warren, F.A. Blazich, and T. G. Ranney. 1999. Nitrogen nutrition of containerized Thuja $\times$ 'Green Giant'. J. Environ. Hort. 17:76-79.

Hart, P.B.S., J.H. Rayner, and D.S. Jenkinson. 1986 Influence of pool substitution on the interpretation of fertilizer experiments with ${ }^{15} \mathrm{~N}$. J. Soil Sci. 37:389-403.

Hauck, R.D. 1978. Critique of field trials with isotopically labeled nitrogen fertilizer, p. 63-77. In: D.R. Nielsen and J.G. MacDonald (eds.). Nitrogen in the environment. Academic Press, New York.

Hauck, R.D. and J.M. Bremner. 1976. Use of tracers for soil and fertilizer nitrogen research. Adv. Agron. 26:219-266.

Horneck, D.A., J.M. Hart, K. Topper, and B. Kopsell. 1989. Methods of soil analysis used in the soil testing laboratory at Oregon State University. Ore. State Univ. Agr. Expt. Sta., Corvallis.

Ivy, R.L., T.E. Bilderback, and S.L. Warren. 2002. Date of potting and fertilization affects plant growth, mineral nutrient content, and sub- strate electrical conductivity. J. Environ. Hort. 20(2):104-109.

Jansson, S.L. and J. Persson. 1982. Mineralization and immobilization of soil nitrogen, p. 229-252. In F.J. Stevenson et al. (eds.). Nitrogen in agricultural soils. ASA-SSA Agron. Monogr. 22.

Jenkinson, D.S., R.H. Fox, and J.H. Rayner. 1985. Interactions between fertilizer nitrogen and soil nitrogen: The so-called "priming" effect. J. Soil Sci. 36:425-444.

Meinzer, F.C. and J. Zhu. 1998. Nitrogen stress reduces the efficiency of the $\mathrm{C}_{4} \mathrm{CO}_{2}$ concentrating system, and therefore quantum yield, in Saccharum (sugarcane) species. J. Expt. Bot. 49:1227-1234.

Newton, I. 1687. Philosophiae naturalis principia mathematica. I. Newton Publ.

Olson, R.V. 1980. Fate of tagged nitrogen fertilizer applied to irrigated corn. Soil Sci. Soc. Amer. J. 44:514-517.

Olson, R.V. and C.W. Swallow. 1984. Fate of labeled nitrogen applied to winter wheat for five years. Soil Sci. Soc. Amer. J. 48:583-586.

Ranjith, S.A. and F.C. Meinzer. 1997. Physiological correlates of variation in nitrogen-use efficiency in two contrasting sugarcane cultivars. Crop Sci. 37:818-825.

Rao, A.C.S., J.L. Smith, R.I. Papendick, and J.F. Parr. 1991. Influence of added nitrogen interactions in estimating recovery efficiency of labeled nitrogen. Soil Sci. Soc. Amer. J. 55:1616-1621.

Rose, M.A., J.W. White, and M.A. Rose. 1994. Maximizing nitrogen-use efficiency in relation to the growth and development of poinsettia. HortScience 29(4):272-276.

Rose, M.A. and B. Biernacka. 1999. Seasonal patterns of nutrient and dry weight accumulation in Freeman maple. HortScience 34(1):91-95.

Russelle, M.P., E.J. Deibert, R.D. Hauck, M. Stevanovic, and R.A. Olson. 1981. Effects of water and nitrogen management on yield and ${ }^{15} \mathrm{~N}$-depleted fertilizer use efficiency of irrigated corn. Soil Sci. Soc. Amer. J. 45:553-558.

Sage, R.F. and R.W. Pearcy. 1987. The nitrogen use efficiency of $\mathrm{C}_{3}$ and $\mathrm{C}_{4}$ plants. Plant Physiol. 84:959-963.

Tolman, D.A., A.X. Niemiera, and R.D. Wright. 1990. Influence of plant age on nutrient absorption for marigold seedlings. Hortscience 25(12):1612-1613.

Torbert, H.A., R.L. Mulvaney, R.M. Vanden Heuvel, and R.G. Hoeft. 1992. Soil type and moisture regime effects on fertilizer efficiency calculation methods in a nitrogen-15 tracer study. Agron. J. 84:66-70.

Tyler, H.H., S.L. Warren, and T.E. Bilderback. 1996. Reduced leaching fractions improve irrigation use efficiency and nutrient efficacy. J. Environ. Hort. 14(4):199-204.

Walters, D.T. and G.L. Malzer. 1990. Nitrogen management and nitrification inhibitor effect on nitrogen-15 urea: I. Yield and fertilizer use efficiency. Soil Sci. Soc. Amer. J. 54:115-122.

Westerman, R.L. and L.T. Kurtz. 1974. Isotopic and nonisotopic estimations of fertilizer nitrogen uptake by sudangrass in field experiments. Soil Sci. Soc. Amer. Proc. 38:107-109.

Whitcomb, C.E. 1986. Landscape plant production, establishment, and maintenance. Lacebark Inc., Stillwater, Okla.

Wood, L.E., C.V. Cole, L.K. Porter, and D.C. Coleman. 1987. Transformation of added and indigenous nitrogen in gnotoblastic soil: A comment on the priming effect. Soil Biol. Biochem. 19:673-678. 